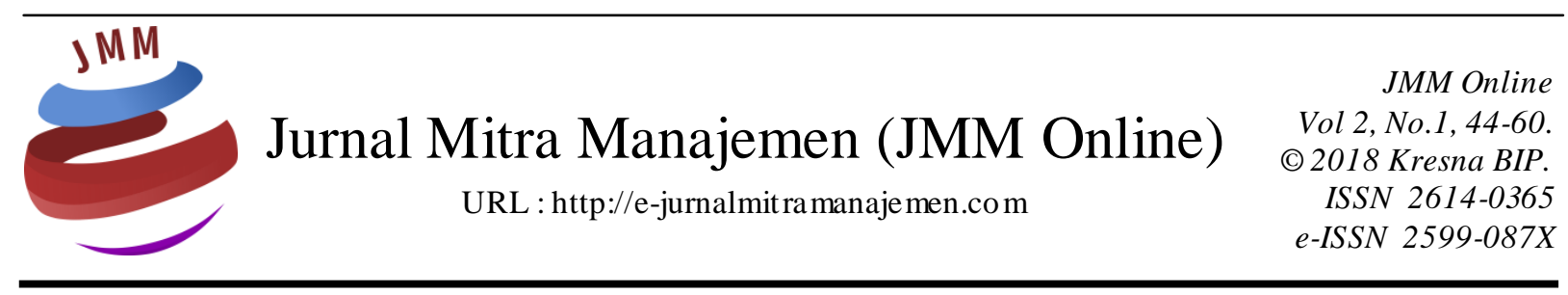

\title{
MODEL PRODUKTIVITAS KAR YAWAN DITINJAU DARI KREATIVITAS TERKAIT OTOMATISASI MESIN PADA PERUSAHAAN MEBEL DI JAWA TIMUR
}

\author{
H. Hidayat ${ }^{1}$, Bachtiar Rahman Malik ${ }^{2}$, Woro Utari ${ }^{3}$ \\ Universitas Wijaya Putra, Surabaya
}

INFORMASI ARTIKEL

Dikirim : 4 Januar 2018

Revisi pertama:5 Januari 2018

Diterima : 6 Januari 2018

Tersedia online : 23 Januari 2018

Kata Kunci : Model, Produktivitas, Kreativitas

Email : masday_brew@yahoo.co.id

\section{ABSTRAK}

Penelitian yang berjudul Model Pengembangan Produktivitas Karyawan Melalui Kreativitas Pada Perusahaan Mebel di Jawa Timur ini bertujuan untuk mengetahui pengaruh kreativitas karyawan terhadap produktivitas karyawan. Disamping itu mengetahui dimensi kreativitas yang mempengaruhi produktivitas karyawan. Jenis penelitian ini eksplanatoris menggunakan pendekatan cross sectional study untuk mengetahui produktivitas karyawan dan beberapa dimensi kreativitas yang menentukan produktivitas karyawan tersebut. Populasi dalam penelitian ini adalah semua perusahaan mebel di Jawa Timur sebanyak 248. Penelitian ini terdiri dari dua kelompok sampel yaitu sampel perusahaan dan sampel karyawan bagian produksi perusahaan mebel di Jawa Timur. Pengambilan sampel perusahaan ditentukan melalui teknik purposive, sehingga didapatakan sebanyak 15 perusahaan. Sedangkan sampel karyawan ditentukan dengan cara stratified quota random sampling, sehingga didapatkan jumlah sampel karyawan pada masing-masing perusahaan sebanyak 15 karyawan. Jumlah total sampel karyawan pada penelitian ini sebanyak 225 karyawan. Hasil penelitian ini menyebutkan bahwa kreativitas karyawan secara simultan berpengaruh langsung signifikan terhadap produktivitas karyawan, ada perbedaan produktivitas karyawan pada tingkat kreativitas yang berbeda pada perusahaan mebel di Jawa Timur. Adapun secara parsial bahwa hanya dimensi individu yang berpengaruh signifikan terhadap produktivitas karyawan, sedangkan dimensi kelompok dan dimensi perusahaan tidak berpengaruh signifikan terhadap produktivitas karyawan pada perusahaan mebel di Jawa Timur. 


\section{PENDAHULUAN \\ Latar Belakang}

Pada saat ini permasalahan perusahaan pada umumnya adalah adanya perubahan pasar global yang begitu cepat, semakin singkatnya daur hidup produk, inovasi teknologi, ketersediaan informasi yang semakin mudah dan cepat, sekaligus menghadapi perubahan budaya dan sosial yang semakin cepat.

Sistem pada perusahaan manufaktur, umumnya aktifitas perusahaan sekitar 70 $\%$ ada pada fungsi produksi yakni tanah, modal dan tenaga kerja (Heizer dan Render, 2006). Faktor tenaga kerja memiliki kontribusi terbesar (Schroeder, 1989), lebih spesifik lagi masalah manajemen tenaga kerja, karena kunci keberhasilan fungsi manajemen perusahaan ada pada faktor sumberdaya manusianya (Stevenson, 1996). Akar permasalahan pada perusahaan adalah mengelola sumberdaya manusia untuk meningkatkan produktivitas perusahaan melalui produktivitas tenaga kerja.

Salah satu hal terpenting agar perusahaan mebel tetap exis, kuncinya ada pada produktivitas karyawan. Sejumlah faktor yang mempengaruhi standar kualitas produk perusahaan melalui peran sumber daya manusia yang efektif dan efisien dalam perusahaan semakin penting (Stoner et al., 1995). Sumberdaya manusia merupakan sumber daya terpenting dalam suatu perusahaan (Robbins dan Handoko, 2000), dengan demikian dimensi utama dalam kehidupan perusahaan adalah sumber daya manusia (West MA, 2000).

Kualitas sumberdaya manusia dalam perusahaan adalah yang memiliki kemampuan, meliputi pengalaman kerja dan ketrampilan yang baik (David, 2001). Disamping itu menyangkut dua aspek yakni aspek fisik (kualitas fisik ) dan aspek nonfisik (kualitas non-fisik) yang menyangkut kemampuan bekerja, berfikir dan ketrampilan-ketrampilan lain.

Salah satu dimensi produktivitas karyawan adalah kinerja karyawan yang dipengaruhi oleh banyak faktor berkaitan dengan manajemen salah satunya adalah kreativitas karyawan.

Perusahaan mebel harus melakukan inovasi-inovasi baru untuk mengantisipasi daur hidup produk (Product Life Cycle) dalam wujud menghasilkan produk yang berkualitas yang tidak menyalahi ketentuan yang berlaku dengan memenuhi standard kualitas konsumen. Oleh karena itu diperlukan kreativitas karyawan untuk meningkatkan produktivitasnya. Perusahaan mebel (furniture) di Jawa Timur juga mengalami permasalahan yang hampir sama seperti perusahaan lain yaitu ketidakstabilan produktivitas karyawan.

Alasan meneliti produktivitas kerja karyawan karena :

1) Produktivitas karyawan pada perusahaan belum mencapai standar (BPTK Propinsi Jawa Timur, 2015).

2) Ingin mengetahui faktor-faktor yang mempengaruhi produktivitas karyawan. Alasan penelitian ini mengambil obyek pada perusahan mebel karena produk mebel merupakan produk yang cukup kompetitif, hal itu terbukti dengan:

1) Perusahaan dalam industri mebel cukup banyak.

2) Nilai eksport mebel mulai tahun 2011 hingga tahun 2015 terus mengalami kenaikan dan diprediksi nilai eksport tahun 2005 juga mengalami kenaikan, demikian juga peluang untuk eksport tahun berikutnya (Ketua Asmindo, 2015). 
Penelitian ini ingin mengetahui faktor-faktor yang mempengaruhi produktivitas karyawan. Berdasarkan penelitian terdahulu, peneliti memasukkan variabel kreativitas sebagai variabel baru dalam kajian produktivitas karyawan. Masuknya variabel kreativitas merupakan nilai tambah bagi hasil penelitian ini dibanding penelitian sebelumnya, sehingga penelitian ini termasuk penelitian pengembangan.

\section{Rumus an Masalah}

Berdasarkan latar belakang, maka rumusan masalah dalam penelitian ini :

1. Apakah kreativitas karyawan berpengaruh secara signifikan terhadap produktivitas karyawan?.

2. Dimensi kreativitas apa saja yang mempengaruh produktivitas karyawan?.

\section{Tujuan Penelitian}

Secara umum tujuan penelitian ini adalah menguji dan menganalisis pengaruh perbedaan kreativitas karyawan terhadap produktivitas kerjanya pada perusahaan mebel di Jawa Timur. Secara khusus tujuan penelitian ini adalah :

Mengetahui pengaruh langsung kreativitas karyawan terhadap produktivitas karyawan. Mengetahui dimensi kreativitas yang mempengaruh produktivitas karyawan.

\section{Manfaat Penelitian}

Secara umum manfaat penelitian adalah mengembangkan variabel yang mempengaruhi produktivitas karyawan perusahaan pada umumnya dan produktivitas karyawan perusahaan mebel pada khususnya.

Secara praktis penelitian ini bermanfaat memberikan masukan bagi manajer perusahaan mebel di Jawa Timur tentang pengaruh perbedaan kreativitas terhadap produktivitas karyawan.

\section{KAJIAN PUSTAKA \\ Definisi Produktivitas}

Secara umum, produktivitas diartikan sebagai hubungan antara hasil nyata maupun fisik dengan masukan yang sebenarnya (ILO, 1979). Greenberg yang dikutip oleh Sinungan (1985) mengartikan produktivitas sebagai perband ingan antara totalitas pengeluaran pada waktu tertentu dibagi totalitas masukan selama periode tersebut.

Pengertian lain produktivitas adalah sebagai tingkatan efisiensi dalam memproduksi barang-barang atau jasa-jasa: Produktivitas mengutarakan cara pemanfaatan secara baik terhadap sumber-sumber dalam memproduksi barang-barang. Produktivitas juga diartikan sebagai :

a. Perbandingan ukuran harga bagi masukan dan hasil.

b. Perbedaan antara kumpulan jumlah pengeluaran dan masukan yang dinyatakan dalam satu- satuan (unit) umum.

Produktivitas adalah suatu konsep universal yang menciptakan lebih banyak barang dan jasa bagi kehidupan manusia dengan menggunakan sumberdaya yang serba terbatas (Tarwaka, Bakri dan Sudiajeng, 2004; 137) 
(Meneze, 2006; in the Hussain Nagvi, 2013) defined Productivity as the employee's ability produce work goods or services according to the exected standards set by the employersor beyond the expected standards.

Dalam berbagai referensi terdapat banyak sekali pengertian mengenai produktivitas, namun rumusan tradisional bagi keseluruhan produktivitas tidak lain ialah ratio dari pada apa yang dihasilkan (output) terhadap keseluruhan peralatan produksi yang dipergunakan (input).

\section{Konsep Produk tivitas}

Peningkatan produktivitas dan efisiensi merupakan sumber pertumbuhan utama untuk mewujudkan pembangunan yang berkelanjutan. Sebaliknya, pertumbuhan yang tinggi dan berkelanjutan juga merupakan unsur penting dalam menjaga kesinambungan peningkatan produktivitas jangka panjang. Dengan demikian, pertumbuhan dan produktivitas bukan dua hal yang terpisah atau memiliki hubungan satu arah, melainkan keduanya adalah saling tergantung dengan pola hubungan yang dinamis, tidak mekanistik, non linear dan kompleks.Secara makro, sumber pertumbuhan dapat dikelompokkan kedalam unsur berikut:

Peningkatan stok modal sebagai hasil akumulasi dari proses pembangunan yang terus berlangsung. Proses akumulasi ini merupakan hasil dari proses investasi. Peningkatan jumlah tenaga kerja juga memberikan kontribusi terhadap pertumbuhan ekonomi.

Peningkatan produktivitas merupakan sumber pertumbuhan yang bukan disebabkan oleh peningkatan penggunaan jumlah dari input atau sumber daya, melainkan disebabkan oleh peningkatan kualitasnya. Dengan jumlah tenaga kerja dan modal yang sama, pertumbuhan output akan meningkat lebih cepat apabila kualitas dari kedua sumber daya tersebut meningkat.Walaupun secara teoritis faktor produksi dapat dirinci, pengukuran kontribusinya terhadap output dari suatu proses produksi sering dihadapkan pada berbagai kesulitan.

Konsep produktivitas kerja dapat dilihat dari dua dimensi, yaitu dimensi individu dan dimensi organisasian. Dimensi individu melihat produktivitas dalam kaitannya dengan karakteristik-karakteristik kepribadian individu yang muncul dalam bentuk sikap mental dan mengandung makna keinginan dan upaya individu yang selalu berusaha untuk meningkatkan kualitas kehidupannya. Sedangkan dimensi keorganisasian melihat produktivitas dalam kerangka hubungan teknis antara masukan (input) dan keluaran (output). Oleh karena itu dalam pandangan ini, terjadinya peningkatan produktivitas tidak hanya dilihat dari aspek kuantitas, tetapi juga dapat dilihat dari aspek kualitas. Kedua pengerian produktivitas tersebut mengandung cara atau metode pengukuran tertentu yang secara praktek sukar dilakukan. Kesulitankesulitan itu dikarenakan, pertama karakteristik-karakteristik kepribadian individu bersifat kompleks, sedangkan yang kedua disebabkan masukan-masukan sumber daya bermacam- macam dan dalam proporsi yang berbeda-beda.

Produktivitas kerja sebagai salah satu orientasi manajemen dewasa ini, keberadaannya dipengaruhi oleh berbagai faktor. Faktor-faktor yang mempengaruhi terhadap produktivitas pada dasarnya dapat diklasifikasikan kedalam dua jenis, yaitu 
pertama faktor-faktor yang berpengaruh secara langsung, dan kedua faktor-faktor yang berpengaruh secara tidak langsung.

\section{Definisi Kreativitas}

Kreativitas merupakan potensi yang dimiliki setiap manusia dan bukan yang diterima dari luar diri individu. Kreativitas yang dimiliki manusia, lahir bersama lahirnya manusia tersebut. Sejak lahir individu sudah memperlihatkan kecenderungan mengaktualisasikan dirinya. Dalam kehidupan ini kreativitas sangat penting, karena kreativitas merupakan suatu kemampuan yang sangat berarti dalam proses kehidupan manusia. Harus diakui bahwa memang sulit untuk menentukan satu definisi yang operasional dari kreativitas, karena kreativitas merupakan konsep yang majemuk dan multidimensional sehingga banyak para ahli mengemukakan tentang definisi dari kreativitas.

Menurut Conny R Semiawan (2009: 44) kreativitas adalah modifikasi sesuatu yang sudah ada menjadi konsep baru. Dengan kata lain, terdapat dua konsep lama yang dikombinasikan menjadi suatu konsep baru.

Sedangkan menurut Utami Munandar (2009: 12), bahwa kreativitas adalah hasil interaksi antara individu dan lingkungannya, kemampuan untuk membuat kombinasi baru, berdasarkan data, informasi, atau unsur-unur yang sudah ada atau dikenal sebelumnya, yaitu semua pengalaman dan pengetahuan yang telah diperoleh seseorang selama hidupnya baik itu di lingkungan sekolah, keluarga, maupun dari lingkungan masyarakat.

Menurut Barron yang dikutip dari Ngalimun dkk (2013: 44) kreativitas didefinisikan sebagai kemampuan untuk menciptakan sesuatu yang baru. Guilford yang dikutip dari Ngalimun dkk (2013: 44) menyatakan bahwa kreativitas mengacu pada kemamampuan yang menandai seorang kreatif.

Gowan (2011:51) menjelaskan kreativitas kaitannya dengan keberbakatan menyatakan bahwa keberbakatan adalah hasil dari berfungsinya secara total otak manusia, sehingga kreativitas pun adalah pernyataan tertinggi keberbakatan bisa di teliti dari dasar biologis otak.

Iklim yang mendukung kreativitas diantaranya keterbukaan dilingkungan dilingkungan kerja, persuasif, tidak otoriter, memotivasi, menghargai tenaga kerja baik kelebihan maupun kekurangannya, memberi kebebasan terpimpin, menghindari hukuman yang berlebihan, dan memberi kesempatan terbuka untuk memberi pengalaman.

\section{Konsep Kreativitas}

Kreativitas merupakan kemampuan yang mencerminkan kelancaran, keluwesan (fleksibilitas), dan originalitas dalam berfikir, serta kemampuan untuk mengelaborasi suatu gagasan (Munandar, 2009 : 47).

Definisi Kreativitas dari Clark berdasarkan hasil berbagai penelitian tentang spesialisasi belahan otak, mengemukakan kreativitas merupakan ekspresi tertinggi keterbakatan dan sifatnya terintegrasikan, yaitu sintesa dari semua fungsi dasar manusia yaitu: berfikir, merasa, menginderakan dan intuisi (basic function of thingking, feelings, sensing and intuiting). 
Konsep kreativitas, pengertian kreativitas dapat di tinjau dari empat segi (3P dari kreativitas) yaitu:

a) Kreativitas sebagai Proses

Kreativitas adalah suatu proses yang menghasilkan sesuatu yang baru, apakah suatu gagasan atau suatu objek dalam suatu bentuk atau susunan yang baru Proses kreatif sebagai munculnya dalam tindakan suatu produk baru yang tumbuh dari keunikan individu di satu pihak, dan dari kejadian, orang-orang, dan keadaan hidupnya dilain pihak. Jadi Kreativitas sebagai proses: Bersibuk diri secara kreatif yang menunjukan kelancaran fleksibilitas (keluwesan) dan orisinalitas dalam berfikir dan berperilaku.

b) Kreativitas sebagai Produk

Definisi pada dimensi produk merupakan upaya mendefinisikan kreativitas yang berfokus pada produk atau apa yang dihasilkan oleh individu baik sesuatu yang baru/original atau sebuah elaborasi/penggabungan yang inovatif. "Creativity is the ability to bring something new into existence" (Baron, 1976). Definisi yang berfokus pada produk kreatif menekankan pada orisinalitas, seperti yang dikemukakan oleh Baron (1976) yang menyatakan bahwa kreatifitas adalah kemampuan untuk menghasilkan atau menciptakan sesuatu yang baru. Begitu pula menurut Haefele, 1998 (dalam Munandar, 2009) menyatakan kreativitas adalah kemampuan untuk membuat kombinasi-kombinasi baru yang mempunyai makna sosial. Dari dua definisi ini maka kreatifitas tidak hanya membuat sesuatu yang baru tetapi mungkin saja kombinasi dari sesuatu yang sudah ada sebelumnya.

Kecuali unsur baru, juga terkandung peran faktor lingkungan dan waktu (masa). Produk baru dapat disebut karya kreatif jika mendapatkan pengakuan (penghargaan) oleh masyarakat pada waktu tertentu. Namun menurut ahli lain pertama- tama bukan suatu karya kreatif bermakna bagi umum, tetapi terutama bagi si pencipta sendiri.

c) Kreativitas ditinjau dari segi Pribadi

Kreativitas merupakan ungkapan unik dari seluruh pribadi sebagai hasil interaksi individu, perasaan, sikap dan perilakunya. Sebagai pribadi: Kreativitas mencerminkan keunikan individu dalam pikiran-pikiran dan ungkapan-ungkapannya. Kreativitas mulai dengan kemampuan individu untuk menciptakan sesuatu yang baru. Biasanya seorang individu yang kreatif memiliki sifat yang mandiri. Ia tidak merasa terikat pada nilai-nilai dan norma- norma umum yang berlaku dalam bidang keahliannya. Ia memiliki sistem nilai dan sistem apresiasi hidup sendiri yang mungkin tidak sama yang dianut oleh masyarakat ramai. Dengan perkataan lain: Kreativitas merupakan sifat pribadi seorang individu (bukan merupakan sifat sosial yang dihayati oleh masyarakat) yang tercermin dari kemampuannya untuk menciptakan sesuatu yang baru.

Kreativitas pada dimensi person adalah upaya mendefinisikan kreativitas yang berfokus pada individu atau person dari individu yang dapat disebut kreatif. Guilford menerangkan bahwa kreativitas merupakan kemampuan atau kecakapan yang ada dalam diri seseorang, hal ini erat kaitannya dengan bakat. Dalam mendefinisikan pribadai kreatif sekarang, perlu diperhatikan 4 kriteria dasar menurut Guilford 
(1957) dan Jackson \& Messick (1965) yang dikutip dari Kemendiknas (2011) sebagai berikut:

a. Orisinal (original), perilaku yang tidak biasa dan di luar dugaan (mengejutkan) daripada hal yang khas dan dapat diprediksi.

b. Sesuai dan berkaitan (appropriate and relevant), perilaku kreatif memiliki kesesuaian dan berkaitan dengan tujuan dari seseorang ketika ia membuat sesuatu.

c. Kelancaran (fuent) yang menghasilkan sesuatu yang baru dalam bentuk yang berarti, perilaku kreatif menunjukkan kelancaran yang berkaitan dengan kreativitas dan dapat disamakan dengan kelancaran dalam berbahasa, hal ini dimaksudkan bahwa seorang anak dapat menghasilkan sebuah ide dengan mudah setelah menghasilkan ide sebelumnya.

d. Fleksibel (flexible) dalam mengembangkan dan menggunakan pendekatan yang tidak biasanya dalam memecahkan masalah.

\section{METODE PENELITIAN}

\section{Rancangan Penelitian}

Penelitian ini mengujipengaruh perbedaan kreativitas terhadap produktivitas karyawan. Ruang lingkupnya para karyawan di lingkungan perusahaan mebel di Jawa Timur. Jenis penelitian eksplanatoris karena : 1) Menjelaskan gejala yang ditimbulkan oleh obyek penelitian. 2) Peneliti berusaha mencari jawaban terhadap fenomena faktorfaktor yang mempengaruhi produktivitas karyawan perusahaan mebel di Jawa Timur. 3) Menguji hubungan antar variabel yang dihipotesiskan (Donald dan William, 1997).

Penelitian ini menggunakan pendekatan cross sectional study untuk mengetahui produktivitas karyawan dan hal-hal terkait kreativitas yang menentukan produktivitas karyawan tersebut. Variabel-variabel yang diidentifikasi mempengaruhi produktivitas karyawan adalah kreativitas karyawan.

Pelaksanaan penelitian dilakukan dalam dua tahap yang meliputi yaitu :

1. Persiapan dan fleksibilitas data yang akan dikumpulkan

2. Pengumpulan data primer dari isian kuesioner untuk karyawan dan data sekunder dari pencatatan yang ada di perusahaan mebel di Jawa Timur serta wawancara langsung dengan responden maupun pimpinan responden di perusahaan.

\section{Populasi}

Populasi dalam penelitian ini adalah semua perusahaan mebel yang ada di Jawa Timur sebanyak 248.

\section{Sampel dan Teknik Pengambilan Sampel}

Ada dua kelompok sampel yaitu sampel perusahaan mebel dan sampel karyawan bagian produksi di perusahaan mebel di Jawa Timur.

\section{Sampel Pe rusahaan Sampel}

Pengambilan sampel perusahaan ditentukan secara purposive berdasarkan justifikasi peneliti yaitu pada 5 (lima) kota yang memiliki jumlah perusahaan mebel terbanyak di Jawa Timur, maka sampel yang digunakan dalam penelitian ini sebanyak 15 perusahaan yaitu sebagai berikut: 
Tabel 1. Jumlah Sampel Perusahaan berdasarkan Kota di Jawa Timur

\begin{tabular}{llll}
\hline No & Kota & Populasi & $\begin{array}{l}\text { Sampel } \\
\text { Perusahaan }\end{array}$ \\
\hline 1 & Surabaya & 36 & 4 \\
\hline 2 & Pasuruan & 32 & 3 \\
\hline 3 & Sidoarjo & 26 & 3 \\
\hline 4 & Malang & 26 & 3 \\
\hline 5 & Gresik & 16 & 2 \\
\hline 6 & Kota Lain & 112 & 0 \\
\hline Jumlah & 248 & 15 \\
\hline
\end{tabular}

Sumber : Data Primer (2017) Diolah

\section{Sampel Karyawan}

Pengambilan sampel karyawan ditentukan setelah sampel perusahaan terpilih dengan langkah- langkah sebagai berikut:

1. Menentukan jumlah sampel karyawan dengan cara stratified quota random sampling.

2. Menentukan jumlah sampel karyawan pada masing-masing perusahaan sebanyak 15 karyawan.

3. Sampel karyawan pada penelitian ini sebanyak 225 karyawan.

\section{Kerangka Operasional Penelitian}

1. Instrumen penelitian yang digunakan adalah kuesioner.

2. Data yang telah terkumpul dianalisis menggunakan alat analisis statistik yaitu Model Persamaan Struktural (structural equation modeling).

3. Data dianalisis dan diintepretasikan untuk digunakan dalam penarikan kesimpulan dan rekomendasi.

\section{Identifikasi Variabel \\ Variabel dan Definisi Operasional \\ Variabel}

1. Produktivitas karyawan merupakan jumlah komponen produk berkualitas yang terselesaikan pada waktu standard.

2. Kreativitas merupakan penemuan pola-pola makna yang melintasi berbagai bidang pengetahuan dan pengalaman. Dalam hal ini kreativitas merupakan gagasan yang digunakan dalam pemecahan masalah. Kreativitas diukur dalam :

a. Kepekaan masalah yaitu respon karyawan terhadap masalah baru, sehingga menghasilkan gagasan baru

b. Struktur tugas yaitu mekanisme atau prosedur kerja yang berkaitan dengan fasilitas kerja, otonomi dan kontrol organisasi dalam membangun kreativitas karyawan melalui kesempatan mengeluarkan gagasan.

c. Strategi manajemen produksi yaitu penerapan strategi manajemen produksi yang memberikan toleransi kesalahan karyawan dan peluang menyampaikan gagasan. 


\section{Teknis Pengukuran Indikator Variabel Produktivitas Karyawan}

Pengukuran produktivitas karyawan dilakukan dengan cara mengukur indeks produktivitas karyawan yaitu membandingkan hasil produksi karyawan perorangan dengan hasil produksi standard. Hasil produksi karyawan merupakan perbandingan jumlah unit komponen mebel yang dihasilkan karyawan pada waktu kerja (jam kerja). Produksi standard merupakan jumlah unit komponen mebel yang dihasilkan pada waktu standard. Waktu standard adalah waktu yang dibutuhkan secara wajar oleh seorang karyawan normal untuk menyelesaikan pekerjaan berupa komponen mebel sesuai dengan bagian tugasnya dalam sistem kerja.

Secara teknis langkah-langkah pengukuran produktivitas karyawan dalam penelitian ini sebagai berikut :

1. Peneliti melakukan pengukuran waktu dalam menyelesaikan 1 (satu) unit komponen mebel. Pengukuran dilakukan selama 4 jam atau 240 menit waktu produktif yang dilakukan selama observasi.

2. Menghitung waktu rata-rata untuk menghasilkan 1 (satu) komponen produk. Perhitungannya adalah membagi waktu 240 menit dengan jumlah komponen produk yang dihasilkan.

3. Menetapkan faktor rating. Supaya waktu yang diperoleh sama, maka diperlukan angka koefisien atau faktor yang disebut faktor rating. Perhitungan faktor rating dalam penelitian ini menggunakan cara model Barnas dalam buku "Motion and Time Study ; Design and measurement of Work", yaitu ada 4 (empat) faktor yang mempengaruhi rating faktor yaitu Skill, Effort, Condition, and Consistency.

4. Penghitungan waktu normal adalah jumlah waktu rata-rata daripengamatan ditambah rating faktor.

5. Menetapkan waktu longgar yaitu waktu yang diijinkan oleh mandor/pengawas las is ten supervisor kepada karyawan dalam bekerja.

6. Menetapkan waktu standard yang dihitung berdasarkan jumlah waktu normal dengan waktu longgar.

7. Menghitung produktivitas karyawan yaitu membagi jumlah komponen hasil produksi selama waktu produktif pada saat observasi yaitu selama 240 menit.

8. Menghitung indeks produktivitas karyawan yaitu membagi produktivitas karyawan dengan waktu standard.

\section{Teknik Pengumpulan Data}

Kuesioner, instrumen kuesioner untuk mengumpulkan data terutama yang berkaitan dengan kreativitas karyawan.

Wawancara, digunakan untuk memperoleh data jumlah komponen produk yang dihasilkan karyawan pada waktu produktif.

Observasi, digunakan memperoleh data produktivitas karyawan dan waktu standard yang menghasilkan satu komponen produk pada bagian produksi tempat responden bekerja.

Dokumentasi, digunakan untuk memperoleh data yang berkaitan dengan data lain yang menunjang penelitian. 


\section{Model dan Teknik Analisis}

Analisis yang digunakan dalam penelitian ini :

1. Analisis diskriminan digunakan untuk mengetahui variabel yang mempunyai pengaruh dominan.

2. Analisis Lisrel menggunakan SEM untuk mengetahui jalur yang mempunyai pengaruh lebih kuat

3. Analisis Regresi Berganda untuk mengetahui pengaruh variabel bebas terhadap variabel terikat.

4. Metode Kualitatif digunakan untuk menganalisis data yang diperoleh hasil wawancara dan observasi.

\section{Uji Validitas dan Reliabilitas}

\section{Uji Validitas}

Ketepatan indikator dalam mengukur konstruk ditelusuri melalui analisis validitas konstruk (Dillon W.R. dan Goldstein, 1994). Untuk mengukur konstruk yang dimaksudkan oleh peneliti, melalui validitas konvergen dan validitas diskriminan (Furgon, 2007). Indikator dapat dikatakan memiliki convergen validity apabila indikator tersebut mempunyai nilai standardized regression weight $>0,50$ (Hair et al., 1992). Discriminant validity dilakukan agar skala yang digunakan dalam penelitian tidak memiliki dua konstruk yang mengukur hal yang berbeda, maka korelasi antar konstruk harus < 0,90. Jika korelasi antar konstruk mencapai 0,90 atau lebih akan terjadi multikolinieritas antar konstruk (Cooper, 1997).

\section{Uji Reliabiltas}

Uji reliabilitas dilakukan pada indikator (item atau observable variable atau criterion) yang mengukur konstruk (faktor atau variabel atau predictor). Hal ini dilakukan karena variabel tidak diukur secara langsung, tetapi diukur melalui indikator dari setiap konstruk. Dengan melihat nilai squared multiple correlatin $\left(\mathrm{R}^{2}\right)$ sebagai fungsi beta dan korelasi antar predictor (konstruk) dan criterion (indikator), akan menyatakan besarnya kemampuan indikator untuk menjelaskan konstruk yang diukurnya. Semakin rendah nilai $\mathrm{R}^{2}$ berarti indikator yang bersangkutan makin tidak baik menjelaskan konstruk yang seharusnya diukur. Dengan kata lain nilai $\mathrm{R}^{2}$ menyatakan keterandalan (reliabilitas) kemampuan mengukur (menjelaskan) variabel terhadap konstruknya.

Tingkat reliabilitas indikator sebagai alat ukur dalam penelitian ini dapat dilihat pada $\mathrm{R}^{2}$ masing-masing indikator terhadap konstruknya, yaitu pada persamaan pengukuran.

\section{Teknik Analisis Data}

Metode analisis data yang digunakan dalam penelitian ini dikelompokkan menjadi dua yaitu analisis statistik deskriptif dan analisis statistik inferensial.

1. Analisis statistik deskriptif

Analisis ini digunakan untuk mendeskripsikan variabel penelitian, tanpa menarik generalisasi. Data yang telah dikumpulkan selanjutnya diedit dan ditabulasikan dalam tabel dan dilakukan pembahasan secara deskriptif.

2. Analisis statistik inferensial 
Analisis ini digunakan untuk menguji pengaruh kreativitas terhadap produktivitas karyawan. Teknik analisis statistik inferensial menggunakan SPSS. Untuk mengetahui pengaruh secara simultan dimensi kreativitas terhadap produktivitas menggunakan uji $\mathrm{F}$, sedangkan untuk mengetahui pengaruh dimensi kreativitas terhadap produktivitas menggunakan uji-t.

\section{Pengujian Ge jala Pe nyimpangan As umsi Klasik}

Menurut Gujarati (1995) penghitungan dalam analisis regresi berganda haruslah memenuhi asumsi-asumsi klasik, seperti asumsi bebas dari Multikolinieritas, Heteroskedastisitas, Kenormalan, dan Linieritas.

Multikolinier artinya adanya korelasi linier yang tinggi (mendekati sempurna) diantara dua atau lebih variabel bebas. Mengetahui ada tidaknya multikolinier antar variabel salah satu caranya bisa dilihat dari Variance Inflation Factor (VIF) dari masing-masing variabel bebas terhadap variabel terikat. Apabila nilai VIF tidak lebih dari 10, itu mengindikasikan bahwa dalam model tidak terdapat multikolinieritas.

Uji heterokedastisitas dilakukan dengan Rank Spearman. Satu variabel bebas dikatakan tidak menyebabkan terjadinya heterokedastisitas apabila korelasi variabel tersebut (Xi ) dengan nilai absolut adalah tidak nyata. Untuk mengetahui hasil uji heterokedastisitas dipergunakan uji $t$, jika sig $t>a$ maka tidak terjadi heterokedastisitas.

Uji asumsi kenormalan dapat dilakukan dengan menggunakan Uji Kolmogorov Smirnov. Uji ini dilakukan dengan melihat nilai selisih yang diperoleh antara peluang kumulatif dari observasi dengan peluang secara teoritis. Untuk menentukan apakah sebaran normal atau tidak dapat dilihat dari nilai 2 tailed $\mathrm{p}$ dibandingkan dengan $\alpha$, jika 2 tailed $p>\alpha$ berarti data tersebar normal.

Pengujian linieritas ini dilakukan untuk mengetahui model yang dibuktikan merupakan model linier atau tidak. Pengujian linieritas dalam penelitian ini dilakukan dengan menggunakan Standarlized Scatterplot, dimana asumsi ini akan terpenuhi jika plot antara nilai residual dengan nilai prediksi tidak membentuk suatu pola tertentu (acak).

\section{HASIL DAN PEMBAHASAN \\ Karakteristik Sampel \\ Karakteristik Sampel Perusahaan}

Berdasarkan hasil observasi dan wawancara dengan manajer produksi di perusahaan mebel diperoleh data sebagai berikut:

a. Pada perusahaan mebel kategori besar

a. Sebagian besar menggunakan proses produksi secara terputus-putus (intermitten process).

b. Komponen mebel dibagi-bagi menjadi banyak sub komponen.

c. Sebagaian besar karyawan bagian produksi adalah wanita.

d. Mandor atau assisten supervisor memimpin satu bagian.

b. Pada perusahaan mebel kategori sedang 
a. Proses produksi sebagian besar menggunakan proses terputus-putus (intermitten process) dan sebagian menggunakan proses terus menerus (continous process).

b. Komponen mebel dibagi-bagi menjadi sub komponen, tetapi tidak sebanyak pada perusahaan besar.

c. Sebagian besar karyawan bagian produksi adalah laki-laki.

d. Mandor atau asisten supervisor membawahi beberapa bagian.

\section{Deskripsi Variabel Penelitian}

Persepsi subyek penelitian karyawan Mebel di Jawa Timur terhadap variabel penelitian pada perusahaan tempat mereka bekerja dapat dilihat pada hasil diskriptif variabel-variabel penelitian sebagai berikut :

\section{Kreativitas}

Kreativitas karyawan dalam penelitian ini adalah karyawan yang dapat memikirkan pendekatan-pendekatan yang berbeda dan lebih efektif dengan cara menghasilkan gagasan-gagasan baru.

Persepsi karyawan tentang indikator variabel kreativitas karyawan dalam penelitian ini sebagai berikut :

a. Kepekaan karyawan terhadap masalah kerja karyawan dapat dikatakan baik sebanyak $79,78 \%$ dan sangat baik sebanyak $20,22 \%$.

b. Struktur tugas persepsi responden dapat dikatakan baik sebanyak $68,95 \%$ dan sangat baik sebanyak $30,32 \%$.

c. Strategi manajemen produksi perusahaan mebel dipersepsi karyawan baik sebanyak $67,15 \%$ dan sangat baik sebanyak $31,05 \%$.

d. Semua indikator kreativitas termasuk kategori baik. Hal tersebut nampak pada pada indikator strategi manajemen produksi skor rata-rata 3,99 (baik), struktur tugas skor rata-rata sebesar 3,91 (baik) dan skor rata-rata terendah pada indikator kepekaan masalah sebesar 3,88 (baik).

\section{Produktivitas Karyawan}

Produktivitas dalam penelitian ini diukur berdasarkan indeks produktivitas, sedangkan indeks produktivitas merupakan rasio antara produktivitas karyawan dengan produktivitas standard. Berdasarkan hasil penelitian ditemukan bahwa :

Produktivitas karyawan, produktivitas standard dan indeks produktivitas karyawan pada perusahaan mebel di Jawa Timur dari 225 responden ada 155 atau sebesar $68.95 \%$ responden indeks produktivitasnya sama dengan satu lebih besar dari satu, sedangkan sebanyak 70 atau sebesar $31.05 \%$ responden indeks produktivitasnya kurang dari satu.

\section{Produktivitas Karyawan dari Perspektif Kreativitas Karyawan}

Hasil analisis deskriptif antara variabel kreativitas dengan produktivitas karyawan yang diukur melalui indeks produktivitas dapat dibaca pada tebel berikut : 
Tabel 2. Indeks Produktivitas Karyawan Berdasarkan Kreativitas

\begin{tabular}{|c|c|c|c|c|c|c|c|}
\hline \multirow{3}{*}{\multicolumn{2}{|c|}{$\begin{array}{l}\text { Rata-Rata } \\
\text { Skor } \\
\text { Kreativitas }\end{array}$}} & \multicolumn{6}{|c|}{ Indeks Produktivitas } \\
\hline & & \multicolumn{2}{|c|}{$\begin{array}{l}\text { Kurang } \\
\text { dari } 1\end{array}$} & \multicolumn{2}{|c|}{$\begin{array}{l}\text { Sama } \\
\text { dengan } \\
\text { atau lebih } \\
\text { dari 1 }\end{array}$} & \multicolumn{2}{|c|}{ Total } \\
\hline & & Jml & $\%$ & $\mathrm{Jml}$ & $\%$ & Jml & $\%$ \\
\hline $\begin{array}{l}1,00 \\
1,08\end{array}$ & - & - & - & - & - & - & - \\
\hline $\begin{array}{l}1,09 \\
2,06\end{array}$ & - & - & - & - & - & - & - \\
\hline $\begin{array}{l}2,07 \\
3,04\end{array}$ & - & - & - & - & - & - & - \\
\hline $\begin{array}{l}3,05 \\
4,02\end{array}$ & - & 53 & 23,47 & 83 & 36,82 & 136 & 60,29 \\
\hline $\begin{array}{l}4,03 \\
5,00\end{array}$ & - & 17 & 7,58 & 72 & 32,13 & 89 & 39,71 \\
\hline Jumlah & & 70 & 31,05 & 155 & 68,95 & 225 & $\overline{100,0}$ \\
\hline
\end{tabular}

Sumber : Data Primer 2017 (Diolah)

Berdasarkan tabel tersebut diatas, sebanyak 155 responden atau 68,95\% memiliki indeks produktivitas sama dengan atau lebih dari satu dan 70 responden atau $31,05 \%$ memiliki produktivitas kurang dari satu. Sebanyak 136 responden atau $60,29 \%$ memiliki kreativitas baik (rata-rata skor 3,05 - 4,02) sebanyak 83 orang $(36,82 \%)$ indeks produktivitasnya sama dengan atau lebih dari satu, sedangkan sisanya sebanyak 53 orang $(23,47 \%)$ indeks produktivitasnya kurang dari satu. Responden yang memiliki kreativitas sangat baik (rata-rata skor 4,03-5,00) sebanyak 89 orang $(39,71 \%)$, dari jumlah tersebut yang memiliki indeks produktivitasnya sama dengan atau lebih dari satu sebanyak 72 orang atau sebesar 32,13\%, sedangkan sisanya sebanyak 17 orang atau 7,58\% indeks produktivitasnya kurang dari satu.

Selanjutnya untuk menguji analisis statistik inferensial dengan menggunakan SPSS (Statistical Program for Social Science) diperoleh sebagai berikut :

Tabel 3. Hasil Analisis Pengaruh Kreativitas Karyawan dilihat dari Dimensi Karakteristik Individu, Karakteristik Kelompok dan Karakteristik Perusahaan terhadap Produktivitas

\begin{tabular}{llllll}
\hline Model & \multicolumn{2}{l}{$\begin{array}{l}\text { Unstandardized } \\
\text { Coefficients }\end{array}$} & $\begin{array}{l}\text { Standardized } \\
\text { Coefficients }\end{array}$ & $\mathrm{t}$ & Sig. \\
\hline 1 (Constant) & .361 & .344 & & 1.047 & .296 \\
\hline $\begin{array}{l}\text { Karakteristik } \\
\text { Individu }\end{array}$ & .261 & .090 & .199 & 2.896 & .004 \\
\hline $\begin{array}{l}\text { Karakteristik } \\
\text { Kelompok }\end{array}$ & -.043 & .080 & -.037 & -.534 & .594 \\
\hline $\begin{array}{l}\text { Karakteristik } \\
\text { Perusahaan }\end{array}$ & .016 & .050 & .020 & .326 & .744 \\
\hline
\end{tabular}

Sumber : Hasil Analisis Data (2017) 
Berdasarkan hasil analisis data tersebut dapat diketahui pengaruh kreativitas karyawan dilihat dari dimensi karakteristik individu, karakteristik kelompok dan karakteristik perusahaan secara parsial terhadap Produktivitas yang dapat dijelaskan sebagai berikut:

1. Nilai t hitung untuk kreativitas karyawan dari dimensi karakteristik individu sebesar 2.896 dengan tingkat signifikansi sebesar 0.004 karena nilai signifikansi (lebih kecil dari 0,05), maka kreativitas karyawan dari dimensi karakteristik individu mempunyai pengaruh yang signifikan terhadap produktivitas.

2. Nilai t hitung untuk kreativitas karyawan dari dimensi karakteristik kelompok sebesar -0.534 dengan tingkat signifikansi sebesar 0.594 karena nilai signifikansi (lebih besar dari 0,05), maka kreativitas karyawan dari dimensi karakteristik kelompok tidak mempunyai pengaruh yang signifikan terhadap produktivitas.

3. Nilai t hitung untuk kreativitas karyawan dari dimensi karakteristik perusahaan sebesar 0.326 dengan tingkat signifikansi sebesar 0.744 karena nilai signifikansi (lebih besar dari 0,05), maka kreativitas karyawan dari dimensi karakteristik perusahaan tidak mempunyai pengaruh yang signifikan terhadap produktivitas.

Selanjutnya untuk menguji pengaruh kreativitas karyawan dilihat dari dimensi karakteristik individu, karakteristik kelompok dan karakteristik perusahaan secara simultan terhadap Produktivitas digunakan analisis dengan uji $\mathrm{F}$ yang dapat dilihat pada tabel berikut:

Tabel 4. Hasil Analisis of Varians (ANOVA)

\begin{tabular}{|c|c|c|c|c|c|}
\hline Model & $\begin{array}{l}\text { Sum of } \\
\text { Squares }\end{array}$ & $\mathrm{df}$ & $\begin{array}{l}\text { Mean } \\
\text { Square }\end{array}$ & $\bar{F}$ & Sig. \\
\hline 1 Regression & 1.610 & 3 & .537 & 3.437 & $.017^{\mathrm{a}}$ \\
\hline Residual & 42.618 & 273 & .156 & & \\
\hline Total & 44.227 & 276 & & & \\
\hline
\end{tabular}

Sumber : Hasil Analisis Data (2017)

Berdasarkan hasil analisis data diperoleh nilai uji $\mathrm{F}$ hitung sebesar 3.437 dengan tingkat signifikansi sebesar 0.017 artinya bahwa kreativitas karyawan dilihat dari dimensi karakteristik individu, karakteristik kelompok dan karakteristik perusahaan secara simultan berpengaruh signifikan terhadap Produktivitas.

Besarnya konstribusi kreativitas karyawan dilihat dari dimensi karakteristik individu, karakteristik kelompok dan karakteristik perusahaan terhadap Produktivitas dapat dilihat pda tabel berikut:

Tabel 5. Model Summary

\begin{tabular}{|c|c|c|c|c|}
\hline Model & $\mathrm{R}$ & $\begin{array}{l}\mathrm{R} \\
\text { Square }\end{array}$ & $\begin{array}{l}\text { Adjusted } \\
\mathrm{R} \\
\text { Square }\end{array}$ & $\begin{array}{l}\text { Std } \\
\text { Error of } \\
\text { The } \\
\text { Estimate }\end{array}$ \\
\hline 1 & $.191^{\mathrm{a}}$ & .036 & .026 & .39511 \\
\hline
\end{tabular}

Sumber : Hasil Analisis Data (2017)

Dari nilai koefisien determinasi. Hasil analisis data menunjukkan bahwa koefisien determinasi R Square sebesar 0.36 atau sebesar 3.6\% Artinya bahwa sebesar $3.6 \%$ produktivitas dapat dijelaskan oleh kreativitas karyawan dilihat dari dimensi 
karakteristik individu, karakteristik kelompok dan karakteristik perusahaan, sedangkan sisanya sebesar $96.4 \%$ dijelaskan oleh variabel lain diluar peneltian ini.

\section{Produktivitas Karyawan dari Perspektif Proses Produksi}

Hasil observasi dalam penelitian berkaitan dengan proses produksi, peneliti menyimpulkan bahwa :

1. Semua perusahaan sampel dalam penelitian ini memproduk mebel menggunakan proses produksi terputus-putus (intermitten). Alat yang digunakan sebagian besar menggunakan mesin, bahkan di beberapa perusahaan besar menggunakan mesin outomatis.

2. Pada perusahaan besar hampir semua komponen produk diproses menggunakan mesin automatis, hanya komponen-komponen khusus yang masih menggunakan mesin konvensional.

3. Pada perusahaan sedang hampir semua komponen produk diproses menggunakan mesin konvensional, hanya komponen-komponen khusus yang menggunakan mesin automatis, bahkan masih ada yang masih menggunakan cara-cara tradisional (tidak menggunkan mesin).

Lebih jelasnya kaitan antara penggunaan mesin dalam proses produksi dengan produktivitas karyawan, produktivitas standard dan indeks produktivitas karyawan dapat dilihat pada tabel berikut :

Tabel 6. Indeks Produktivitas Karyawan Berdasarkan Jenis Mesin

\begin{tabular}{|c|c|c|c|c|c|c|c|}
\hline \multirow{3}{*}{ No } & \multirow{3}{*}{ Proses Produksi } & \multicolumn{6}{|c|}{ Indeks Produktivitas } \\
\hline & & \multicolumn{2}{|c|}{$\begin{array}{l}\text { Kurang dari } \\
\text { satu }\end{array}$} & \multicolumn{2}{|c|}{$\begin{array}{l}\text { Sama dengan atau } \\
\text { lebih dari satu }\end{array}$} & \multicolumn{2}{|c|}{ Total } \\
\hline & & Jml & $\%$ & $\mathrm{Jml}$ & $\%$ & $\mathrm{Jml}$ & $\%$ \\
\hline 1 & Mesin Outomatis & 28 & 12,64 & 114 & 50,54 & 142 & 63,18 \\
\hline 2 & $\begin{array}{l}\text { Mesin } \\
\text { Konvensional }\end{array}$ & 35 & 15,52 & 41 & 18,41 & 76 & 33,57 \\
\hline 3 & $\begin{array}{l}\text { Tidak } \\
\text { menggunakan } \\
\text { Mesin }\end{array}$ & 7 & 2,89 & 1 & 0,36 & 7 & 3,25 \\
\hline Jun & lah & 70 & 31,05 & 155 & 68,95 & 225 & 100,00 \\
\hline
\end{tabular}

Sumber : Data Primer (Diolah), 2016

Berdasarkan tabel tersebut, maka dapat dijelaskan sebagai berikut:

1. Ada 142 responden $(63,18 \%)$ yang menggunakan mesin outomatis. Dari jumlah tersebut sebanyak 28 responden $(12,64 \%)$ indeks produktivitasnya kurang dari satu, sedangkan 114 orang $(50,54 \%)$ indeks produktivitasnya sama dengan atau lebih dari satu.

2. Ada 76 responden $(33,57 \%)$ yang menggunakan mesin konvensional. Responden yang memiliki indeks produktivitas sama dengan atau lebih dari satu sebanyak 41 orang $(18,41 \%)$, lebih banyak dibandingkan 35 responden $(15,53 \%)$ yang memiliki indeks produktivitas kurang dari satu. 


\section{Temuan Teoritis}

Sebagaimana telah diuraikan pada tujuan dan manfaat penelitian ini diharapkan dapat memberikan sumbangan pengembangan ilmu pengetahuan di bidang manajemen terutama tentang variabel-variabel yang mempengaruhi produktivitas karyawan perusahaan pada umumnya dan produktivitas karyawan perusahaan mebel pada khususnya. Temuan penelitian ini adalah : Kreativitas karyawan berpengaruh terhadap produktivitas karyawan.

\section{Keterbatasan Penelitian}

Hasil penelitian ini memberikan sejumlah temuan, akan tetapi ada beberapa hal yang perlu dikaji lebih lanjut. Perlunya keberlanjutan penelitian ini karena dipengaruhi oleh keterbatasan yang ada pada penelitian ini. Keterbatasan tersebut meliputi :

1. Masih banyak variabel lain yang mempengaruhi produktivitas karyawan.

2. Pengukuran produktivitas berdasarkan indeks produktivitas karyawan menghasilkan komponen produk mebel, bukan produk akhir (mebel).

3. Variasi komponen mebel yang digunakan untuk mengukur produktivitas karyawan sangat banyak.

4. Penelitian ini hanya dilakukan pada perusahaan yang sudah eksis lima tahun.

5. Sampel perusahaan hanya perusahaan kategori sedang saja, tidak termasuk perusahaan kecil yang membutuhkan kreativitas lebih tinggi.

6. Indikator kreativitas hanya sebatas mengukur penyampaian ide dan gagasan saja, belum sampai pada action.

\section{Rekomendasi Bagi Peneliti Yang akan Datang}

Berdasarkan hasil penelitian dan keterbatasan penelitian ini, maka rekomendasi pada peneliti mendatang sebagai berikut :

1. Perlu menambah variabel lain yang mempengaruhi produktivitas karyawan.

2. Hampir semua karyawan perusahaan mebel bekerja secara Tim, maka perlu diteliti produktivitas kelompok kerja karyawan.

3. Pengukuran produktivitas karyawan berdasarkan produk akhir (bukan komponen produk).

4. Pengukuran Indikator kreativitas tidak hanya mengukur penyampaian ide dan gagasan saja, tetapi action kreativitas.

\section{KESIMPULAN DAN SARAN}

Berdasarkan hasil penelitian, analisis data, dan pembahasan yang telah dilakukan, maka hasil penelitian ini disimpulkan bahwa kreativitas karyawan berpengaruh secara signifikan terhadap produktivitas karyawan pada perusahaan mebel di Jawa Timur.

Dimensi kreativitas yang berpengaruh signifikan terhadap produktivitas karyawan adalah karakteristik individu yang terkait dengan kepekaan merespon sesuatu untuk menemukan gagasan maupun metode kerja baru. Sedangkan dimensi karakteristik kelompok dan karakteristik perusahaan berpengaruh tidak signifikan terhadap kreativitas karyawan.

Temuan lain, kreativitas dimensi individu juga disebabkan tingkat otomatisasi peralatan yang digunakan. Semakin sederhana peralatan yang digunakan jika untuk 
meningkatkan produktivitas karyawan maka dibutuhkan semakin tinggi tingkat kreativitas karyawan.

\section{DAFTAR PUSTAKA}

Ambarita, Jerry Paska, dan I Nengah Kartika. 2015. Pengaruh Luas Lahan, Penggunaan Pestisida, Tenaga Kerja, Pupuk terhadap Produksi Kopi di Kecamatan Pekutatan Kabupaten Jembrana. E-Jurnal Ekonomi Pembangunan Universitas Udayana 4(7): 776-793.

Andari Sukma Pradnyani, Cok Istri, dan I Gusti Bagus Indrajaya. 2014. Analisis Skala Ekonomi dan Efisiensi pada Usaha Perkebunan Kakao di Kecamatan Abiansemal Kabupaten Badung. E-Jurnal Ekonomi Pembangunan Universitas Udayana, 3(9): 403-412.

Belay, Alemu Moges., Petri, Helo, dan Josu Takala., Fentahun, Moges Kasie. 2011. Effects of Quality Management Practices and Concurrent Engineering in Business Performance. International Journal of Business and Management 6(3): 345-355.

Blackwell, dan Bacon Susan. 1994. Personal Efficiency and Productivity: Do You Match Up. Journal of Management Development Review. 7(5): 134-145.

Blackwell, Bacon Susan. 1994. Personal Efficiency and Productivity: Do You Match Up, Journal of Management Development Review, Vol 7 No. 5, MCB. University Press.

Bobbe, Richard A., Schaffer, dan Robert H. 1993. Productivity Improvement Manage It or Buy It Business Horizons. Tesis. Indiana University. US A.

Campbell, Mike, Giles, dan Lesley. 2003. The Productivity and Skill Challenge. Journal of Industrial and Commercial Training 35(1): 433-453.

Campbell, Mike, Giles, dan Lesley. 2003. The Productivity and Skill Challenge. Journal of Industrial and Commercial Training 35(2): 234-246.

Dewi, Indira Shinta. 2012. Pengaruh Kualitas Bahan Baku Dan Tenaga Kerja Terhadap Peningkatan Kualitas Produk (Studi Empirik Pada Pt. Trimoda Uptodate). Jurnal Ilmiah Satya Negara Indonesia 5(1): 126-132.

Fayzollahi, Sadegh, Alireza Shirmohammadi, dan Behzad Latifian. 2013. The Impact of Environmental Factors on Total Quality Management and Firm Performance:Evidence from Industrial Enterprises in Iran. International Research Journal of Applied and Basic Sciences 4(10): 3237-3245.

Fening, Fred Appiah., Pesi Amaria., dan Evelyn Owusu Frempong. 2013. Business Linkages between Total Quality Management and Organizational Survival in Manufacturing Companies in Ghana and Social Science. International Journal Management and Business Webber International University 4(10): 2313-2332.

Fildes, R; Nikolopoulos, K; Crone, S F; Syntetos, A.A. 2008. Forecasting and Operational Research. The Journal of the Operational Research Society, 59(1): $1150-1172$.

Flynn, Barbara B., Roger G. Schroeder, dan Sadao Sakakibara. 1994. A Framework For Quality Management Research And An Associated Measurement Instrument. Journal of Operations Management 11(3): 339-366. 